\title{
CLINICO-LABORATORY CHARACTERISTICS, RISK FACTORS AND OUTCOME OF ACUTE KIDNEY INJURY
}

\section{Najmush Shakireen ${ }^{\natural}$, Shahzad Ahmad', Rabia Saeed', Arbab Nisar Ahmad', Khushbakht Hussam', Arshad Hussain '}

\begin{abstract}
OBJECTIVE: To determine the clinico-laboratory characteristics, risk factors and outcome related to acute kidney injury $(\mathrm{AKI})$ in hospitalized patients.

METHODS: This prospective study on 101 consecutive patients admitted to the Northwest General Hospital \& Research Centre, Peshawar, Pakistan was carried out from January-March 2019. Patients were staged according to Kidney Disease Improving Global Outcomes (KDIGO) guidelines and outcomes were measured in terms of in-hospital mortality and change in KDIGO staging.

RESULTS: Majority ( $n=57 / 101 ; 56.43 \%)$ were males. Mean age of patients was $57.90 \pm 16.93$ years. Twenty-seven $(26.73 \%)$ patients were in AKI stage-I, $29(28.71 \%)$ in stage-2 and $45(44.55 \%)$ were in stage-3. Hypertension $(n=74 / 101 ; 73.27 \%)$ was the commonest co-morbid condition. Sepsis $(n=39 / 101 ; 38.61 \%)$ and hypovolemia $(n=21 / 101 ; 20.8 \%)$ were most common risk factors for AKI. There was complete recovery in $43(42.57 \%)$ patients. In-hospital mortality was $6.9 \%(n=7 / 101)$ and $57.1 \%(n=4 / 7)$ of these patients had KDIGO stage-3. Serum creatinine levels declined in 22 $(21.78 \%)$ cases, remained static in $23(22.8 \%)$ and worsened in $06(5.9 \%)$ cases. Male gender and presence of hypovolumia $(p<0.05)$ significantly differed in survivors compared to non-survivors. Furthermore, factors associated with declined in serum creatinine included stage-II AKI and length of hospital stay, while stage-II and III AKI on admission, absence of oliguria crude odd ratio (COR: 2.68I, $\mathrm{p}=0.027,95 \% \mathrm{Cl}: \mathrm{I} .12-6.44$ ) and lower serum creatinine levels on admission (cOR: $0.668, \mathrm{p}<0.00 \mathrm{I}, 95 \% \mathrm{Cl}$ : 0.54-0.83) were associated with complete recovery.
\end{abstract}

CONCLUSION: Sepsis and hypovolemia constituted the major risk factors. Gender and hypovolemia were the significant factors between the survivors and non-survivors.

KEYWORDS: Acute Kidney Injury (MeSH); Patient Outcome Assessment (MeSH); KDIGO (Non-MeSH); Fatal Outcome (MeSH); Mortality (MeSH); Sepsis (MeSH); Oliguria (MeSH).

THIS ARTICLE MAY BE CITED AS: Shakireen N, Ahmad S, Saeed R, Ahmad AN, Hussam K, Hussain A. Clinico-laboratory characteristics, risk factors and outcome of acute kidney injury. Khyber Med Univ J 202I;I3(I):30-5. DOI: https://doi.org/l 0.35845/kmuj.202I.20430.

\section{INTRODUCTION}

$\Delta$ cute kidney injury (AKI) is a common complication which physicians come across in daily practice and is associated with serious adverse outcomes. It is defined according to Kidney Disease Improving Global Outcomes (KDIGO) criteria as an increase in serum creatinine of $\geq$ $0.3 \mathrm{mg} / \mathrm{dl}(\geq 26.5 \mathrm{~mol} / \mathrm{l})$ within 48 hours and is due to multiple factors including comorbidities, hemodynamic compro- mise, and the drugs causing direct injury to the kidneys.' AKI has significant longterm implications on patient health leading to recurrent hospital admission and long-term mortality. ${ }^{2-6}$

The incidence of AKI has greatly increased in the last few years and differs according to the criteria used to diagnose AKI with poor prognosis having morbidity from $3 / 1000$ to $5 / 1000$ in the United States. ${ }^{6}$ In a study done in China, it was concluded that there were 1.4 to 2.9
I: Department of Medicine \& Allied, Northwest General Hospital \& Research Centre, Peshawar, Khyber Pakhtunkhwa, Pakistan.

Cell \#: +92-313-951।1139

Email冈:dr.nwgh@gmail.com

Date Submitted: July 13,2020

Date Revised: March 24, 2021

Date Accepted: March 25,202I

million patients diagnosed with $\mathrm{AKI}$ in 2013 alone. ${ }^{6} \mathrm{AKI}$ results in serious events needing multidisciplinary approach and has amortality rate of $58 \%$ in intensive care units. ${ }^{7}$ The incidence of AKI has not been well established till now and very few studies have pointed out the burden caused by AKI. In a meta-analysis performed in 2012 , the incidence of AKI was reported to be $21.6 \%$ in adults worldwide with $23.7 \%$ incidence in Southern Asia using KDIGO guidelines. ${ }^{8}$ Hospital associated AKI is more common in men as compared to women especially among those who undergone non-cardiac surgery. Sepsis is the leading cause of AKI in critically ill patients, accounting for $50 \%$ of cases. $\mathrm{AKI}$ is also an independent and strong risk factor in ST elevation myocardial infarction patients. ${ }^{10}$ There is very limited data available in Pakistan on AKI despite the fact that it hinder the physician's approach in managing their patients. Our study aimed to find possible risk factors and outcomes related to AKI by applying KDIGO criteria among hospitalized patients.

\section{METHODS}

This prospective study was conducted on patients who were admitted to Department of Medicine and Allied, Northwest General Hospital \& Research Centre, Peshawar, Pakistan, from January 2019 to March 2019. The facility is a tertiary care referral center in Peshawar and has a patient population from throughout Khyber Pakhtunkhwa and Afghanistan region. Informed consent was taken from all the patients and their families. The patients were 
TABLE I: PATIENTS CHARACTERISTICS AMONG BETWEEN SURVIVORS AND NON-SURVIVORS

\begin{tabular}{|c|c|c|c|c|c|}
\hline \multicolumn{2}{|l|}{ Variable } & \multirow{2}{*}{$\begin{array}{c}\begin{array}{c}\text { Total } \\
(n=101)\end{array} \\
57(56.43)\end{array}$} & \multirow{2}{*}{$\begin{array}{c}\text { Survivors } \\
(n=94) \\
\mathbf{N}(\%) \\
50(87.7 \mathrm{I})\end{array}$} & \multirow{2}{*}{$\begin{array}{c}\text { Non- } \\
\text { survivors } \\
(n=7) \\
\mathbf{N}(\%) \\
7(12.28) \\
\end{array}$} & \multirow{3}{*}{$\frac{\text { p-value }}{0.018^{\#}}$} \\
\hline \multirow{2}{*}{ Gender } & Male & & & & \\
\hline & Female & $44(43.56)$ & $44(100)$ & $0(0)$ & \\
\hline \multirow{3}{*}{$\begin{array}{l}\text { KDIGO stage } \\
\text { on admission }\end{array}$} & Stage I & $27(26.73)$ & $26(96.30)$ & I (3.70) & \multirow{3}{*}{$0.703^{\circ}$} \\
\hline & Stage 2 & $29(28.7 I)$ & $27(93.1)$ & $2(6.9)$ & \\
\hline & Stage 3 & $45(44.55)$ & $4 I(9 I . I)$ & $4(8.89)$ & \\
\hline \multirow{5}{*}{$\begin{array}{l}\text { Co-morbid } \\
\text { conditions }\end{array}$} & Hypertension & $74(73.27)$ & $69(93.24)$ & $5(6.76)$ & $1.000^{\circ}$ \\
\hline & Diabetes mellitus & $58(57.43)$ & $53(91.380$ & $5(8.62)$ & $0.696^{\circ}$ \\
\hline & Coronary artery disease & $4 I(40.59)$ & $39(95.12)$ & $2(4.88)$ & $0.698^{\circ}$ \\
\hline & Congestive heart failure & $34(33.66)$ & $33(97.06)$ & $\mathrm{I}(2.94)$ & $0.418^{\circ}$ \\
\hline & Chronic Kidney disease & $21(20.79)$ & $20(95.24)$ & I (4.76) & 1.000 \\
\hline \multirow{2}{*}{$\begin{array}{l}\text { Previous } \\
\text { hospitalization }\end{array}$} & Yes & $61(60.39)$ & $58(95.08)$ & $3(4.92)$ & \multirow{2}{*}{$1.000^{\#}$} \\
\hline & No & $40(39.60)$ & $36(90)$ & $4(10)$ & \\
\hline \multirow{2}{*}{ Dialysis } & No & $83(82.18)$ & $77(92.77)$ & $6(7.23)$ & \multirow{2}{*}{$1.000^{\#}$} \\
\hline & Yes & $18(17.82)$ & $17(94.44)$ & I (5.56) & \\
\hline \multirow{2}{*}{ Oliguria } & Yes & $36(35.64)$ & $3 I(86.1 I)$ & $5(13.89)$ & \multirow{2}{*}{$0.094^{\#}$} \\
\hline & No & $65(64.36)$ & $63(96.92)$ & $2(3.08)$ & \\
\hline \multirow{10}{*}{$\begin{array}{l}\text { Risk factors for } \\
\text { acute kidney } \\
\text { disease }\end{array}$} & Sepsis & $39(38.61)$ & $35(89.74)$ & $4(10.26)$ & $0.425^{\circ}$ \\
\hline & Hypovolemia & $21(20.79)$ & $17(80.95)$ & $4(19.05)$ & $0.033^{\circ}$ \\
\hline & Acute fluid overload & $18(17.82)$ & $17(94.44)$ & $\mathrm{I}(5.56)$ & $1.000^{\circ}$ \\
\hline & Acute Coronary Syndrome & $10(9.91)$ & $9(90)$ & $\mathrm{I}(\mathrm{I0})$ & $0.529^{\circ}$ \\
\hline & Obstructive Uropathy & $09(8.91)$ & $9(100)$ & $0(0)$ & $1.000^{\circ}$ \\
\hline & Drugs & $07(6.93)$ & $7(100)$ & $0(0)$ & $1.000^{\circ}$ \\
\hline & Glomerulonephritis & $04(3.96)$ & $4(100)$ & $0(0)$ & $1.000^{\circ}$ \\
\hline & Respiratory failure & $04(3.96)$ & $4(100)$ & $0(0)$ & $1.000^{\circ}$ \\
\hline & Pigment nephropathy & 이 (0.99) & $\mathrm{I}(100)$ & $0(0)$ & $1.000^{\circ}$ \\
\hline & Contrast induced & $02(1.98)$ & $2(100)$ & $0(0)$ & $1.000^{\circ}$ \\
\hline \multirow{9}{*}{$\begin{array}{l}\text { Reasons for } \\
\text { admission }\end{array}$} & Infectious Disease & $23(22.8)$ & $21(22.3)$ & $2(28.6)$ & \multirow{9}{*}{$0.480^{\circ}$} \\
\hline & Cardiovascular disorders & $21(20.79)$ & $20(95.24)$ & $\mathrm{I}(4.76)$ & \\
\hline & Chronic kidney disease & $18(17.82)$ & $17(94.44)$ & $\mathrm{I}(5.56)$ & \\
\hline & Neurological diseases & $15(14.85)$ & $15(100)$ & 0 & \\
\hline & Respiratory diseases & $9(8.91)$ & $7(77.78)$ & $2(22.22)$ & \\
\hline & Obstructive uropathy & $5(4.95)$ & $5(100)$ & 0 & \\
\hline & Liver disorders & $04(3.96)$ & $4(100)$ & 0 & \\
\hline & Gastrointestinal disorders & $04(3.96)$ & $3(75)$ & I (25) & \\
\hline & $\begin{array}{l}\text { Obstetric related acute } \\
\text { kidney injury }\end{array}$ & $2(1.98)$ & $2(100)$ & 0 & \\
\hline
\end{tabular}

I; Student independent t test , §; Mann whiteny test , *; Chi square test ,\#; Fischer exact test

thoroughly examined and detailed history was taken from everyo subject. Demographic variables and clinico-laboratory parameters were collected on a structured format. Outcomes were defined in terms of KDIGO staging and inhospital mortality. A patient was staged to Stage I, Stage II and Stage III according to rise or fall in serum creatinine levels.

Patients fulfilling KDIGO criteria for AKI were enrolled via non-probability consecutive sampling. Patients with age less than 14 years age and chronic kidney disease (CKD) patients who were on renal replacement therapy were not included in the final data set.

Ethical approval was taken from the Ethics Committee of the Northwest general Hospital \& Research Center, Peshawar, Pakistan.
Descriptive statistics such as frequency (\%) and mean with standard deviation or median (IQR) where appropriate were computed for categorical and numerical variable respectively. Proportions differences were tested using Chi-square statistics or Fischer exact test where applicable. For nonnormally distributed numerical variable median differences was calculated using the Mann Whitney test while in contrast, student independent t-test was used for the normally distributed numerical variable. Logistic regression was used to determine the factors associated with the changes in serum creatinine [declined and resolved]. The analysis was performed using the Statistical Package for Social Sciences (SPSS) $\vee 20.0$. Statistical significance was set at $\mathrm{P}<0.05$.

\section{OPERATIONAL DEFINITIONS}

I. AKI was defined as per KDIGO guidelines as follow:

Stage I: I.5-I.9 times baseline odds ratio (or) $=0.3 \mathrm{mg} / \mathrm{dL}(=26.5 \mathrm{imol} / \mathrm{L})$ increase in the serum creatinine, (and/or) urine output, $0.5 \mathrm{~mL} / \mathrm{kg} / \mathrm{h}$ for 6 - I 2 hour.

Stage 2: 2.0-2.9 times baseline in the serum creatinine (and/or) urine output $<0.5 \mathrm{~mL} / \mathrm{kg} / \mathrm{h}$ for $=12 \mathrm{hr}$.

Stage 3: 3.0 times baseline increase in the serum creatinine to $=4.0 \mathrm{mg} / \mathrm{dL}$ $(=353.6 \mathrm{imol} / \mathrm{L})$ (and/or) urine output of $<0.3 \mathrm{~mL} / \mathrm{kg} / \mathrm{h}$ for $=24 \mathrm{~h}$, or anuria for $=12 \mathrm{~h}$ or the initiation of renal replacement therapy or in patients, 18years, decrease in estimated GFR to $<35$ $\mathrm{mL} / \mathrm{min} / 1.73 \mathrm{~m}^{2}{ }^{1.11}$

2. Obstructive uropathy was defined as the cause of $\mathrm{AKI}$ with radiological evidence and improvement after the relief of obstruction.

3. Drugs were labeled as the cause of $\mathrm{AKI}$ where there was clinical relation in the absence of other factors causing $\mathrm{AKI}$.

4. Contrast-induced nephropathy was defined as a rise in serum creatinine of $25 \%$ or an absolute increase of serum creatinine of $0.5 \mathrm{mg} / \mathrm{dl}$ within 48 hours after the procedure. ${ }^{12}$

5. Sepsis was defined as patients with suspected or confirmed bacterial infection and presence of $\geq 2$ of the following variables ${ }^{13}$ i.e

a) Glasgow Coma Scale <I5 or Altered mental status

b) Respiratory rate $>22$ /minute

c) Systolic BP $<100 \mathrm{mmHg}$

d) White cell count $>12000 / \mu \mathrm{L}$ or $<4000 / \mu \mathrm{L}$.

6. Hypovolemia is defined as: ${ }^{13}$

a) Decrease in blood pressure less than 90/60mmHg

b) Delayed capillary refill

c) Improvement after normalization of blood flow

7. CKD was defined as patients persistent reduction in eGFR of less than $60 \mathrm{~mL} / \mathrm{min}$ per $1.73 \mathrm{~m}^{2}$ or with 
TABLE II: OUTCOME OF ACUTE KIDNEY INJURY IN TERMS OF KDIGO STAGING AND IN-HOSPITAL MORTALITY

\begin{tabular}{|c|c|c|c|c|c|c|}
\hline \multirow[b]{2}{*}{$\begin{array}{l}\text { IKDIGO stage on } \\
\text { admission }\end{array}$} & \multicolumn{6}{|c|}{ Outcome in terms of KDIGO staging } \\
\hline & $\begin{array}{c}\text { Declined } \\
(n=22) \\
N(\%)\end{array}$ & $\begin{array}{c}\text { Static } \\
(n=23) \\
N(\%)\end{array}$ & $\begin{array}{c}\text { Resolved } \\
(n=43) \\
N(\%)\end{array}$ & $\begin{array}{c}\text { Worsened } \\
(n=6) \\
N(\%)\end{array}$ & $\begin{array}{l}\text { Death } \\
(n=7) \\
N(\%)\end{array}$ & $\begin{array}{c}\text { Total } \\
(n=|2|) \\
N(\%)\end{array}$ \\
\hline Stage I & $\mathrm{I}(3.70)$ & $2(7.40)$ & $21(77.78)$ & $2(7.40)$ & $\mathrm{I}(3.70)$ & $27(26.73)$ \\
\hline Stage 2 & $8(27.59)$ & $5(17.24)$ & $\mathrm{II}(37.93)$ & $3(10.35)$ & $2(6.89)$ & $29(28.7 \mathrm{I})$ \\
\hline Stage 3 & $13(28.89)$ & $16(35.56)$ & II (24.44) & $\mathrm{I}(2.22)$ & $4(8.89)$ & $45(44.56)$ \\
\hline
\end{tabular}

radiological and biochemical evidence of chronic kidney disease for more than 03 months. ${ }^{13}$

\section{RESULTS}

All patients were classified as per KDIGO guidelines. Twenty seven $(26.73 \%)$ patients were in AKI stage I, 29 (28.7I\%) patients were in stage II and 45 (44.55\%) patients were in stage III (Table I). Hypertension ( $n=74 / 10$ I; $73.27 \%)$ was the most common co-morbid condition followed by diabetes mellitus $(n=58 /$ I0I; $57.43 \%)$. Of the total, $36(35.64 \%)$ patients were oliguric at presentation. Dialysis was required in 18 (17.82\%) cases. Sepsis ( $n=39 / 101 ; 38.61 \%)$ and hypovolemia $(n=2 \mathrm{I} / \mathrm{I} 0 \mathrm{I} ; 20.8 \%)$ were the most common risk factors for AKI. Infectious diseases ( $n=23 / 101 ; 22.8 \%$ ), cardiovascular disorders $(n=2 \mathrm{I} / \mathrm{IO}$; $20.8 \%$ ) and chronic kidney disease $(n=18 / 101 ; 17.8 \%)$ were the common causes for hospitalization.

The mean serum creatinine on admission was $4.50 \pm 3.10 \mathrm{mg} / \mathrm{dL}$ in all patients with $4.35 \pm 2.96 \mathrm{mg} / \mathrm{dL}$ and $6.46 \pm 4.56$ $\mathrm{mg} / \mathrm{dL}$ in survivors and non-survivors respectively $(p=0.085)$. Baseline median (IQR)] serum $\mathrm{K}^{+}$was $4.7 \mathrm{I}(4.72) \mathrm{mmol} / \mathrm{L}$, 4.65 (I.68) $\mathrm{mmol} / \mathrm{L}$ and 4.99 (I.55) $\mathrm{mmol} / \mathrm{L}$ in all patients, survivors and non-survivors respectively $(\mathrm{p}=0.2 \mathrm{I} \mathrm{I})$.

Mean (SD) length of hospital stay was $5.37 \pm 3.37,5.49 \pm 3.356$ and $3.7 I \pm 3.302$ days in all patients, survivors and nonsurvivors respectively $(p=0.180)$. Data regarding the outcome showed that 43 (42.57\%) patients completely recovered from AKI at the time of discharge. Serum creatinine levels declined in 22 $(21.78 \%)$ cases, remained static in 23 $(22.8 \%)$ cases and worsened in 06 $(5.9 \%)$ cases. The outcome was good in KDIGO stage I. Out of 43 cases with fully recovery, 21 (48.8\%) cases were in KDIGO stage I. About $77.78 \%(n=2 \mathrm{I} / 27)$ cases of KDIGO stage I had complete resolution of serum creatinine level at discharge (Table II). Median (IQR)] serum creatinine at discharge was I.8 (I0.4I) mg/dL, I.52 (2.34) mg/dL and $2.30(4.2) \mathrm{mg} / \mathrm{dL}$ in all patients, survivors and non-survivors respectively $(p=0.07 I)$. In-hospital mortality was observed in 7 (6.9\%) cases and $57.1 \%$ $(n=4 / 7)$ of these patients had KDIGO stage 3. Common factors contributing for mortality were hypovolumia and sepsis ( $n=4 / 7 ; 57.14 \%$ each). Out of 21 cases of hypovolumia, $23.8 \%(n=5)$ required dialysis and $19.05 \%(n=4)$ died. While in patients with sepsis $17.94 \%(n=7 / 39)$ required dialysis and $10.25 \%(n=4 / 39)$ died. Out of 18 cases requiring dialysis, $7(38.88 \%)$ had sepsis, $5(27.77 \%)$ had hypovolumia and 3 (16.66\%) had acute circulatory overload (Table III).

Crude Odd ratios (cOR) along with 95\% $\mathrm{Cl}$ were calculated for factors affecting the outcome: change in serum creatinine. Factors associated with declined in serum creatinine included Stage $2 \mathrm{AKI}$ (cOR: 0.095, 95\% Cl: 0.0I-0.77, p= $0.028)$ and length of hospital stay (cOR: I.I52, , 95\% Cl: I.0I-I.38, p =0.039). Patients with CKD, stage II , stage III, AKI on admission, absence of oliguria and low serum creatinine on admission were associated with complete recovery in terms of serum creatinine (Table IV).

\section{DISCUSSION}

The term of AKI has been described from time to time using various criteria. Most of the times in literature, serum creatinine level is the most frequently used marker by the researchers in defining and staging AKI. It can also be defined based on urinary output. The criterion implemented in our study was based on the KDIGO guidelines 20I2, stating that an increase in serum creatinine of $=0.3 \mathrm{mg} / \mathrm{dl}(=26.5 \mathrm{~mol} / \mathrm{l})$ within 48 hours. ${ }^{1}, 14$
It has been observed that a slight increase in $\mathrm{Cr}$ level can increase the relative mortality. AKI is a common cause of an increase in morbidity and mortality among hospitalized patients that also results in an increased hospital stay and a financial burden. ${ }^{15}$ Patients with AKI have three to seven times higher odds for deaths compared to non-AKI admissions. ${ }^{8}$ The presence of CKD and other concomitant condition raises the risk of AKI.

Studies have been done to predict the possible causes and outcomes of patients having AKI. ${ }^{2,15,16}$ To our knowledge, it is the first study in this area conducted outside ICU settings to estimate the risk factors and outcomes in AKI patients, using KDIGO definitions.

Hypertension followed by diabetes was the most common co-morbids in our study population. A previous study described the same medical co-morbids in their hospital-acquired acute kidney injury patients. In patients requiring hospitalization for acute health associated problems, several factors such as agelinked changes and accompanied comorbidity renders elder population prone to develop AKI. ${ }^{13}$

Primary reasons for admission of the study patients to the hospital included infectious diseases $(n=23,22.8 \%)$, cardiovascular disease $(n=21,20.8 \%)$, chronic kidney disease $(n=18,17.8 \%)$, neurological disease $(n=|5| 4.9 \%$, and respiratory disease $(n=9,8.9 \%)$. Park et al. reported pulmonary disease, gastrointestinal disease, and malignancies to be the primary reason for admission in their study patients. ${ }^{17}$ Previous hospitalization was higher in non-survivors (75\%) as compared to survivors (61.7\%). Previous health status was normal in $39.6 \%$ of patients which is similar to a study conducted in an ICU setting $(41 \%)^{7}$

Studies from India reported that the 
TABLE III: CAUSES AND MANAGEMENT OF ACUTE KIDNEY INJURY

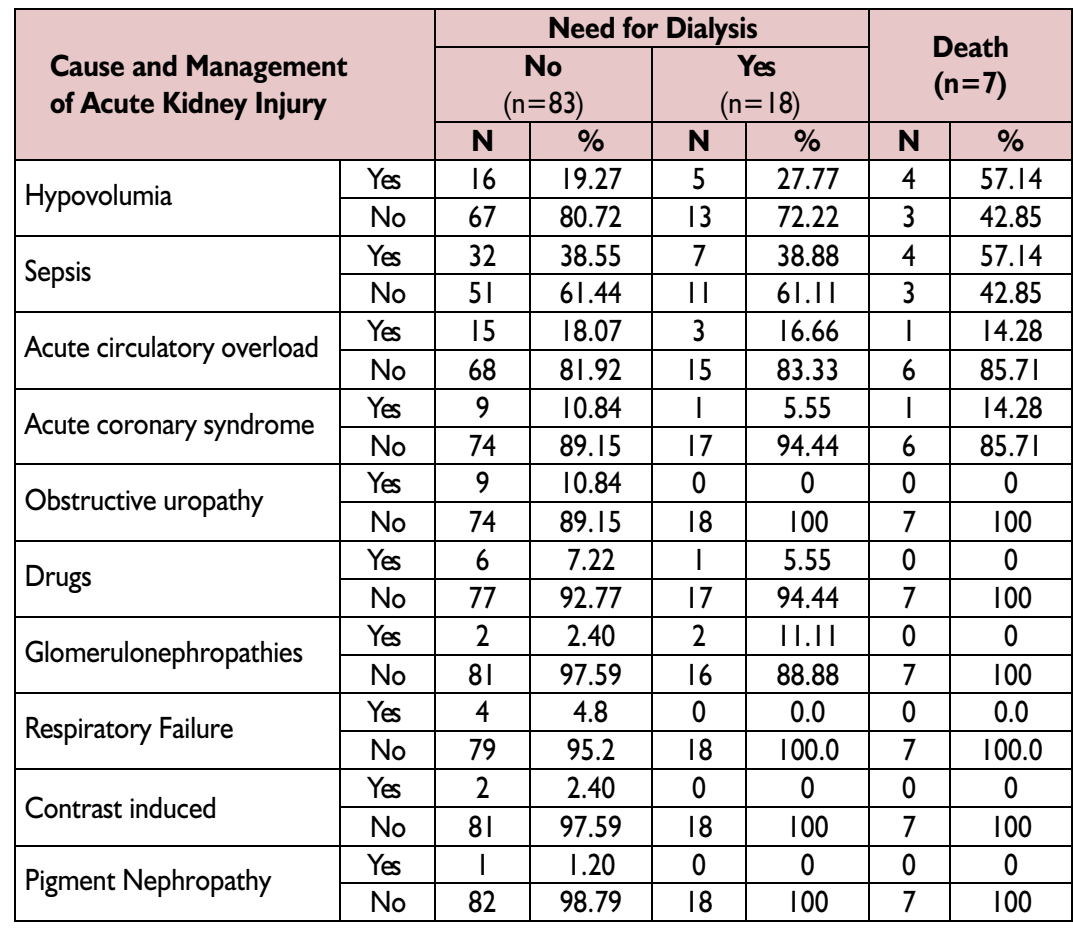

etiology of the AKI haschanged in recent times from drug-induced to sepsis and volume depletion. ${ }^{13,18,19}$ In these studies, sepsis was the most frequently associated factor $(n=39,38.6 \%)$ found among AKI patients, which was $48 \%$ and $34.88 \%$ in other studies. ${ }^{7} 13$ This high incidence of sepsis in our patients may be because most of our patients were from medical units. It is well documented that sepsis attributed to AKI carries high mortality. ${ }^{7,13}$ The presence of $\mathrm{AKI}$ is an independent risk factor in these patients corresponds to in-hospital mortality. Rangel-Frausto et al described that in culture-positive patients, AKI was recorded in $51 \%$ with septic shock, $23 \%$ with severe sepsis, and $19 \%$ with mild to moderate sepsis. ${ }^{20}$ Despite medical advancement the death ratio of severe sepsis has continued to spike. ${ }^{13}$ Compared to nonseptic (45\%) AKI, sepsis-related AKI has a very high mortality (74\%). ${ }^{16}$ Mortality noted in present study was $6.9 \%$, which is less than the reported $10.8 \% 42.8 \%$ globally. ${ }^{16,21,22}$ The reason could be the low number and non-ICU status of the patients in this study. The other possible reasons include a decreased number of days spent in the hospital,the high number of patients in stage I and II AKI according to KDIGO and relatively young population with absence of multiple comorbidites. Sepsis was followed by intravascular volume depletion (2I, 20.8\%) and acute fluid overload $(18,17.8 \%)$ as the most frequently associated factors among our AKI patients. The likelihood of the progression of hospital-acquired AKI increases from 9.2 to 9.4 times in the presence of factors such as volume depletion and congestive cardiac failure. ${ }^{23}$ Poor prognosis was seen in these patients.

Thirty six patients were oliguric of whom, 5 patients died in our study. Such patient tends to have longer dialysis sessions. Oliguria has been recognized as a poor prognostic sign in AKI. Oliguria and high creatinine levels when combined have been presented to estimate the highest mortality in a sample of 32,000 patients. ${ }^{24}$

According to KDIGO staging, the majority of patients (45, 44.55\%) progressed to Stage III and mortality was also highest in stage III $(4,57.1 \%)$. Among those who recovered completely most of them (2I, 48.8\%) belonged to stage I according to KDIGO guidelines. These results resemble the hospitalization and need more regular one concluded in data collected from Asia-Africa. ${ }^{13}$

Gender was found to be associated with in-hospital mortality in $\mathrm{AKI}$ patients in our results, all of them were males which supported results of a metaanalysis of studies providing sexstratified incidence of hospital-acquired acute kidney injury (HAAKI) demonstrates that female sex is associated with protection from AKI. It also concluded that it is male sex that is associated with HAAKI. ${ }^{9}$

Factors affecting the outcome [change in serum creatinine] were determined. Stage II AKI and length of hospital stay were the factors associated with decline in serum creatinine. On the other hand, patients with stage II, III AKI on admission, absence of oliguria, and lower serum creatinine on admission were associated with complete recovery in terms of serum creatinine. Stage II had a significant decline in serum creatinine levels than stage III which may be due to early approach in the management of progressing AKI patients. Similarly, an increase in hospital stay also had a significant decline in serum creatinine levels which support a prolonged monitored approach for AKI patients inside the hospital.. Keeping stage I as a reference, the odds ratio of stage II and stage III was 0.175 and 0.092 respectively. These results can be due to low baseline serum creatinine levels and early renal replacement therapy to these patients. Patients who had mildly functioning kidneys initially with urinary output $>500 \mathrm{ml} / 24 \mathrm{hr}$ had significant recovery than those with oliguria at the time of presentation which shows oliguria a bad prognostic sign. Lower serum creatinine levels on admission were statistically significant regarding complete recovery among AKI patients which means lower baseline serum creatinine can be used as a good prognostic marker among AKI patients.

\section{Strength and Limitation of the Study}

To our knowledge, it is the first study in this region using KDIGO guidelines and estimating in-hospital mortality. The limitation of this study is single center and lack of follow up after discharge from the hospital. Moreover, we acknowledge that our sample size is small, large sample would yield more meaningful insight. 
TABLE IV: FACTOR PREDICTING OUTCOME (CHANGES IN SERUM CREATINE)

\begin{tabular}{|c|c|c|c|c|}
\hline \multicolumn{3}{|c|}{ Parameters } & $\begin{array}{c}\text { Crude Odd } \\
\text { ratios }(95 \% \mathrm{Cl})\end{array}$ & p-value \\
\hline \multirow{6}{*}{$\begin{array}{l}\text { Factors } \\
\text { affecting } \\
\text { decline in } \\
\text { serum } \\
\text { creatinine }\end{array}$} & \multirow{3}{*}{$\begin{array}{l}\text { IKDIGO stage on } \\
\text { admission }\end{array}$} & Stage I & I & \\
\hline & & Stage 2 & $0.095(0.01-0.77)$ & 0.028 \\
\hline & & Stage 3 & $0.935(0.33-2.65)$ & 0.903 \\
\hline & \multicolumn{2}{|c|}{ Length of hospital stay } & $1.152(1.01-1.32)$ & 0.039 \\
\hline & \multirow{2}{*}{ Respiratory failure } & Yes & I & \multirow{2}{*}{0.340} \\
\hline & & No & $0.8 \mathrm{I}(0.0 \mathrm{I}-0.83)$ & \\
\hline \multirow{8}{*}{$\begin{array}{l}\text { Factors } \\
\text { affecting } \\
\text { good } \\
\text { outcome } \\
\text { [Recovery] }\end{array}$} & \multirow{2}{*}{$\begin{array}{l}\text { Chronic Kidney } \\
\text { Disease }\end{array}$} & Yes & $0.100(0.02-0.46)$ & \multirow{2}{*}{0.003} \\
\hline & & No & I & \\
\hline & \multirow{3}{*}{$\begin{array}{l}\text { KDIGO stage on } \\
\text { admission }\end{array}$} & Stage I & I & \\
\hline & & Stage 2 & $0.175(0.54-0.57)$ & 0.004 \\
\hline & & Stage 3 & $0.092(0.03-0.29)$ & $<0.001$ \\
\hline & \multirow{2}{*}{ Oliguria } & Yes & I & \multirow{2}{*}{0.027} \\
\hline & & No & $2.681(1.12-6.44)$ & \\
\hline & \multicolumn{2}{|c|}{ Baseline serum Creatinine (mean) } & $0.668(0.54-0.83)$ & $<0.001$ \\
\hline
\end{tabular}

ITidney Disease Improving Global Outcomes

\section{CONCLUSION}

The majority of our study patients were in KDIGO stage III and sepsis and hypovolemia constituted the major risk factor. AKI resulted with in-hospital mortality of $6.9 \%$. Male gender and presence of hypovolemia were the significant factors between survivors and non-survivors. Stage II, III AKI on admission, absence of oliguria, and lower serum creatinine levels on admission were associated with complete recovery.

\section{ACKNOWLEDGMENTS}

We would like to express our great thankfulness to Iftikhar Ali, (Pharmacist and Independent researcher), Paraplegic Center, Hayatabad, Peshawar for his support, opinion and contribution.

\section{REFERENCES}

I. Kellum JA, Lameire N, Aspelin P, Barsoum RS, Burdmann EA, Goldstein $\mathrm{SL}$, et al. Kidney disease: improving global outcomes (KDIGO) acute kidney injury work group. KDIGO clinical practice guideline for acute kidney injury. Kidney Int Suppl. 20I2;2(I):I-I38. DOI: 10.1038/ kisup.20I2.I

2. Yang L, Xing G, Wang L, Wu Y, Li S, Xu $\mathrm{G}$, et al. Acute kidney injury in China: a cross-sectional survey. The Lancet. 20I5;386(I0002): I465-7I. DOI: I0.10I6/SOI40-6736(I5)00344-X

3. Shacham $Y$, Leshem-Rubinow $E$, Steinvil A, Assa EB, Keren G, Roth A, et al. Renal impairment according to acute kidney injury network criteria among ST elevation myocardial infarction patients undergoing primary percutaneous intervention: a retrospective observational study. Clin Res Cardiol. 20I4; I03(7):525-32. DOI: 10.1007/s00392-0|4-0680-8

4. Tsai TT, Patel UD, Chang TI, Kennedy KF, Masoudi FA, Matheny ME, et al. Contemporary incidence, predictors, and outcomes of acute kidney injury in patients undergoing percutaneous coronary interventions: insights from the NCDR Cath-PCI registry. JACC Cardiovasc Interv 20I4;7(I): I-9. DOI: 10.1016/j.jcin.2013.06.016

5. Hwang $\mathrm{SH}$, Jeong $\mathrm{MH}$, Ahmed K, Kim MC, Cho KH, Lee MG, et al. Different clinical outcomes of acute kidney injury according to acute kidney injury network criteria in patients between ST elevation and non-ST elevation myocardial infarction. Int J Cardiol 20I I; I50(I): 99-101. DOI: 10.1016/j.ijcard. 2011.03 .039

6. Wang C, Pei Y-Y, Ma Y-H, Ma X-L, Liu Z-W, Zhu J-H, et al. Risk factors for acute kidney injury in patients with acute myocardial infarction. Chin Med J 2019;132(I4):1660-5. DOI: 10.1097/CM9.0000000000000293

7. Brivet FG, Kleinknecht DJ, Loirat P, Landais PJ. Acute renal failure in intensive care units-Causes, outcome, and prognostic factors of hospital mortality: A prospective, multicenter study. Crit Care Med 1996;24(2): 192-8. DOI: 10.1097/00003246199602000-00003

8. Susantitaphong P, Cruz DN, Cerda J, Abulfaraj M, Alqahtani F, Koulouridis I, et al. World incidence of $\mathrm{AKI}$ : a meta-analysis. Clin J Am Soc Nephrol 20I3;8(9): I482-93. DOI: I0.22I5/ CJN.007I0II3

9. Neugarten J, Golestaneh L. Female sex reduces the risk of hospitalassociated acute kidney injury: a meta-analysis. BMC Nephrol 2018;19(I):314. DOI: 10.1186/s |2882-0|8-| | 22-z

10. Aijaz S, Ahmed N, Akhter Z, Sattar S, Lakhani S, Malik R, et al. Clinical characteristics and in-hospital outcome in percutaneous coronary interventions with ST elevation myocardial infarction patients developing acute kidney injury. J Pak Med Assoc 2019 Dec;69(I2): 182733. DOI: I0.5455/JPMA.2348।

II. Khwaja A. KDIGO clinical practice guidelines for acute kidney injury. Nephron Clin Pract 2012;120(4):C |79-84. DOI: I0. I I59/000339789

12. Mohammed NM, Mahfouz A, Achkar K, Rafie IM, Hajar R. Contrastinduced nephropathy. Heart Views 2013;|4(3):106-16. DOI: 10.4103/ 1995-705X.125926

13. Goswami S, Pahwa N, Vohra R, Raju BM. Clinical spectrum of hospital acquired acute kidney injury: A prospective study from Central India. Saudi J Kidney Dis Transpl 2018;29 (4):946-55. DOI: 10.4103/13192442.239650

14. Mataloun SE, Machado FR, Senna APR, Guimarães HP, Amaral JLGd. Incidence, risk factors and prognostic factors of acute renal failure in patients admitted to an intensive care unit. Braz J Med Biol Res 2006;39( I0): |339-47.DOI: |0.| | 86/cc224 |

15. Igiraneza G, Ndayishimiye B, Nkeshimana M, Dusabejambo V, Ogbuagu O. Clinical Profile and outcome of patients with acute kidney injury requiring hemodialysis: two years' experience at a tertiary hospital in Rwanda. Biomed Res Int 2018 Mar 27;2018:1716420. DOI: 


\section{$10.1155 / 2018 / 1716420$}

16. Khalil MAM, Awan S, Azmat R, Khalil MAU, Naseer N, Tan J. Factors affecting inpatient mortality in elderly people with acute kidney injury. Sci World J 2018;2018:2142519. DOI: I0.1I55/2018/2142519

17. Park WY, Hwang EA, Jang MH, Park $\mathrm{SB}, \mathrm{Kim} \mathrm{HC}$. The risk factors and outcome of acute kidney injury in the intensive care units. Korean J Intern Med 2010 Jun;25(2):I8I-7. DOI: I0.3904/kjim.20I0.25.2.I8I

18. Jha V, Malhotra H, Sakhuja V, Chugh K. Spectrum of hospital-acquired acute renal failure in the developing countries Chandigarh study. Quart J Med 1992;83(4):497-505.

19. Singh T, Rathore S, Choudhury T,
Shukla V, Singh D, Prakash J. Hospitalacquired acute kidney injury in medical, surgical, and intensive care unit: A comparative study. Indian J Nephrol 2013;23(I):24-9. DOI: 10.4103/097|-4065.107|92

20. Rangel-Frausto MS, Pittet D, Costigan M, Hwang T, Davis CS, Wenzel RP. The natural history of the systemic inflammatory response syndrome (SIRS): a prospective study. J Am Med Assoc (JAMA) 1995; 273(2): I I 7-23. DOI: I0.100I/jama. 1995.03520260039030

21. Brown JR, Rezaee ME, Marshall EJ, Matheny ME. Hospital mortality in the United States following acute kidney injury. Biomed Res Int 2016; 2016:4278579. DOI:I0.II55/2016/ 4278579
22. Wang HE, Muntner P, Chertow GM, Warnock DG. Acute kidney injury and mortality in hospitalized patients. Am J Nephrol 2012;35(4):349-55. DOI: I0.I I59/000337487

23. Shusterman N, Strom BL, Murray TG, Morrison G, West SL, Maislin G. Risk factors and outcome of hospitalacquired acute renal failure: Clinical epidemiologic study. Am J Med 1987;83(I):65-7I. DOI: 10.1016/ 0002-9343(87)90498-0

24. Kellum JA, Sileanu FE, Murugan R, Lucko N, Shaw AD, Clermont G. Classifying AKI by urine output versus serum creatinine level. J Am Soc Nephrol 2015;26(9):223I-8. DOI: 10.168I/ASN.20I4070724

\section{AUTHOR'S CONTRIBUTION}

Following authors have made substantial contributions to the manuscript as under:

NS: Analysis and interpretation of data, drafting the manuscript, critical review, approval of final version to be published

SA \& ANA: Conception and study design, critical review, approval of final version to be published

RS \& KH: Acquisition of data, drafting the manuscript, approval of final version to be published

AH: Analysis and interpretation of data, critical review, approval of final version to be published

Authors agree to be accountable for all aspects of the work in ensuring that questions related to the accuracy or integrity of any part of the work are appropriately investigated and resolved.

CONFLICT OF INTEREST
Authors declared no conflict of interest
GRANT SUPPORT AND FINANCIAL DISCLOSURE
Authors have declared no specific grant for this research from any
funding agency in the public, commercial or not-for-profit sectors

funding agency in the public, commercial or not-for-profit sectors

\section{DATA SHARING STATEMENT}

The data that support the findings of this study are available from the corresponding author upon reasonable request.

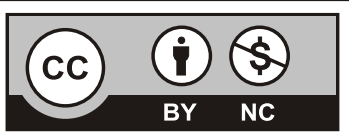

This is an Open Access article distributed under the terms of the Creative Commons Attribution-Non Commercial 2.0 Generic License. 